\title{
The School Career and the Educational Exclusion of the Roma Children in Greece
}

\author{
Christos Tourtouras \\ Associate Professor, Department of Elementary Education \\ Aristotle University of Thessaloniki, Greece \\ Email: htourt@eled.auth.gr \\ Maria Pavlis Korre \\ General Secretariat of Life Long Learning, Greece \\ Email: korre@gsae.edu.gr \\ Argyris Kyridis (Corresponding author) \\ Professor, Department of Early Childhood Education \\ Aristotle University of Thessaloniki, Greece \\ Email: akiridis@ nured.auth.gr
}

Received: February 02, 2016 Accepted: February 05, 2016 Published: February 28, 2016

doi:10.5296/jsr.v7i1.8964 URL: http://dx.doi.org/10.5296/jsr.v7i1.8964

\begin{abstract}
The school career of Roma children in Greece is inevitable connected with their social and educational exclusion from Greek society. The present article examines the main factors which affect the educational status of Roma children and presents a survey which was conducted in the area of Thessaloniki in northern Greece focusing on the school career of 117 Roma children. Following their educational course from primary to secondary school and high school, the survey highlights an extended school failure of Roma children, as there is still a large percentage of children not attending school or presenting poor attendance and leakage from the school system. The survey confirms that for school to become accessible, attractive and effective for children belonging to cultural, ethnic and social minority groups, specific characteristics of each group should be taken into account in the content of analytical school programs across the educational process.
\end{abstract}

Keywords: School career, Education, Reforms 


\section{Introduction}

In the context of a social economic and political system that exists at the base of segregation, discrimination and unequal distribution of wealth worldwide modulated individual perpetuating mechanisms and reproduction of registered logic and ideology. Mechanisms that make up the illusory superstructure respective mineral production relations and of whom, of course, school mechanism is not excluded. As part of the school operation, school failures and exclusions are made, whose real causes are concealed or misrepresented, aiming at consolidating the conviction of an absolute equality of opportunity in education. This is a conviction on the basis of educational failures of many children are justified, serving the social division of labor and reproduce the dominant capitalist system. As part of our commitment at an "unconventional" ideology very different from the dominant, questioning every kind of ideology on equal opportunity in education and equal living conditions in society and choose to highlight those people that specific policies or the lack of specific political make non-visible, both in the education system and the wider social and public space. We emphasize these unseen populations, such as refugees and migrant groups, local minorities and the Roma people, who are recipients of many awards and exclusions in all areas and different countries. Although it is known the extent of school failure and drop this population, however, we consider extremely important the promotion of the exact scope of this with indisputable quantitative data relating to the whole entire school batches of such students' to include any discrepancies between the members of this population group.

Factors that influence and shape the relationship of Roma with the formal education system are many and multi-level. They are connected and mutually dependent on the socioeconomic status of Roma in Greek society. To answer questions related to access, attendance and performance of Roma children in Greek schools, we should first answer the question what is the status of Roma in Greek society, as education is an integral part of, and inevitably linked to, the possible solutions to educational issues facing Roma, within a holistic approach to matters related to them in social and political level.

In this article we will restrict ourselves to the subject of education, and we will try to highlight some important issues related to school attendance and performance of Roma children.

School dropout, school failure and educational exclusion of Roma children are the result of many interacting factors, which are summarized in the first part of this article. In the second part of the article, recording over time the educational process of Roma children in the sample of research in the area of Thessaloniki emerges with quantitative data on the size and range of educational exclusion of Romani children in Greece, along with the complete absence of reports, about their culture, in textbooks core courses in Greek school.

\section{Social Position of Roma in Greece}

Attempting to give a definition for Roma, different approaches from theoretical sociological, historical and political positions of both non-Roma and the Roma themselves, are observed.

Whichever approach we follow or embrace, as if define Roma either as a social group, or as a 
vulnerable social group, either as a minority or cultural, national, ethnic or linguistic group, or if you just say that Roma represent "otherness", the different approaches agree that firstly, Roma have particular cultural elements, secondly, that in Greek society suffer from social exclusion and are constantly low-classified in the Greek social hierarchy, and thirdly, that the education sector cannot be seen detached and fragmented from the whole political and economical field (Author, 2010; FRA- UNDP, 2012).

Gypsies history is also the history of their refusal to be proletarianised (Okley 1983: 53). Outsider groups, such Roma, begin to challenge and contest their lower social position and blocked access to various power resources (Loyal and Quilley, 2004: 15). All attempts to rank groups are racialist and neither ethnically valid or sociologically useful. Gypsies comprise a mosaic of groups with a variety of cultural profiles, with shifting internal boundaries of varying force (Liegeois, 1994:61).

\section{Greek Roma and Education}

In the current legal and institutional framework in Greece, all have access to our educational system. According to xxx \& Author (2011), the education system is presented as neutral and meritocratic, giving to all students equal opportunities for success in order to provide for all social groups the conditions for access and residence, and to prevent school dropout. This is why the curriculum and the educational process should take into consideration specific characteristics of each group.

School institution has no tradition in Roma family. There is no connection between school and social, economic success. Often, school for a Roma is an obstacle to economic and social success, and his/her inclusion in the Roma group to which he/she belongs (Author \& $\mathrm{xxx}$, 1990; xxx \& Author, 2011). Also, school is not very attractive for Roma, and takes no account of their movements and their cultural particularities. Does not prepare teachers adequately, nor other students, to accept and coexist peacefully with Roma children (Author \& xxx, 2011).

Once the Roma children start school, face a different educational system from their own society, and a lot of other problems. Thus, school itself leads them back to exit. There are few times when child and the whole Roma family cannot respond to what are required by school. As Liegeois (1987:163) reports "if we were to represent the elements conveyed in the two systems (organization of space and time, attitudes to various types of behavior, degree of initiative, of independence etc) as two parallel columns, we would see that the parallels conform to their definition, that is, they do not meet-even less so, as most of the elements are in an opposition which is difficult to reduce".

The disadvantaged status of the Roma is reflected in the educational system in many ways (Posavec \& Hrvatic, 2000; Brüggemann, 2012) such as school dropout, the inability of the education system to reach a non-privileged group with different cultural and financial family backgrounds, their priorities in life and the degree associated towards education. Moreover, the arrangement of space in classroom, the tight schedule of program, the requirement to work at home, language, books and the other students, are new and foreign to Roma and 
simultaneously constitute obstacles which have to face. At the same time, Roma family is unable to help children with homework, as parents are often illiterate (Voulgaris, 2014; Biro et al., 2009; Evrodiastasi-Oikokoinonia, 2008; xxx \& Author, 1985). Also, parents' own education has a major effect on many parenting behaviors that can be related with education and academic achievements of their children (Englud et al., 2004). We should however note that Roma recognize the utility that may have the attendance in formal education on their lives (Author \& xxx, 1990; Papakonstantinou et al., 1998 \& 1999). The question however is what school, what structure and contents can meet their own needs.

\section{Stereotypes and Prejudices}

One issue that is also very important, as it directly affects the relationship of children with the formal school system, is prejudice and discrimination from classmates, teachers and non-gypsies parents. Often the existence of stereotyping, prejudice and discrimination are reasons of Roma children's dropouts (Spanoulis, 2014).

In the external evaluation of the educational program "Integration of Roma children in school," stated the negative charge of school community regarding Roma stereotypes which society has already managed to convey to children before school starts to manifest the educational role (Synergon, 2008). Also mentioned is a differentiated behavior towards Roma pupils that contributes to their alienation in the classroom (Forray 2000; Havas 2002). In the same evaluation indicated that rate of $72.8 \%$ of teachers have noticed a tendency of school students to avoid sitting in the same pew with Roma classmates, while important is the proportion of teachers $(37.8 \%)$ referred to aggressive behavior of non-Roma students against Roma students.

Stereotypical perceptions of non-Roma pupils, parents and teachers translated into expectations for similar behavior by Roma pupils, who sometimes stigmatized Roma respond by confirming the phenomenon of self-fulfilling prophecy (Mentor, 1948). According to Schiefele (1986), students' behavior is directly linked to social expectations. Roma are stigmatized by the society in which they live and this is not something caused by them (Goffman, 1963). They lack social acceptance just because they belong to a distinct minority in the framework of a society which is further fragmented and distributed on the basis of very specific roles and functions within the capitalistic system. Additionally, the dominant ideology and the whole superstructure in the capitalistic world denied from the Roma people that political conscience, appropriate to fully understand and to question their given social status and the worst economical conditions they are living in.

\section{Aim of research}

The purpose of the survey is to record and interpret the school courses of Roma students in order to identify the points and cutoff reasons from the educational system. It is crucial to be reflected through research problems related to the integration of Roma in Greek educational system, instead of inventing policies that have nothing to do with the substance of the existing problems. It is clear that the educational paths of students reflect in the most reasonable manner the essence and characteristics of educational inequalities, especially in 
populations that exist largely stereotypical prejudices.

\section{Methodology}

At first, conducted a quantitative content analysis in textbooks of "Language", "Anthology" and "Study of the Environment" of primary school, in order to record references to the group of Roma. In the second level, the almost total absence of such references within the textbooks (it was just one relevant text in the textbook of "Language" of 5th grade in primary school, A' Volume, pp. 77, entitled "Our friends Roma") invited us to focus on gathering data related to the school career of Roma children. This was a descriptive quantitative field survey on 177 Roma students.

The survey was conducted in secondary (Gymnasium) and high school (Lyceum), which are established in Roma campsite in the school years 2011-2012 and 2012-2013. Four full school cohorts of Roma students were studied, by their entrance at secondary School from 2006-2007 up to 2009-2010 (143 children in total). The children that completed their attendance in high school went to high school where the recording continued. There was extra care to provide information on students' performance in primary school. In this way, supervision of the general course until graduation from post-compulsory secondary education and entering or not a higher education institution, was possible.

The same procedure was also followed at another secondary school that was not a pure school of Roma students. There was searched every Roma student enrolled -and attended or not attended at all- during all years, the first entry from 1989-1990 until 2012-2013. They were individuals (34 children) for extended range of more than two decades (from 1989 to 1990 up to 2012-2013).

The survey was conducted on-site using registration data from the official records of the three schools, concerning the school career of Roma children (performance in the last grade of primary school and all classes of secondary and high school, frequency and types of stagnation and dropouts per class, religion, birth years, first enrollment and graduation from secondary and high school separately, transfers from/to other schools, course directional choices in high school and, finally, the official results of entrance or not in tertiary institutions by the specific computer lists from Ministry of Education).

Finally, the data analysis was conducted with the SPSS program, on the basis of Inferential and Descriptive Statistics. 


\section{Macrothink}

\section{Results}

1. School Performance in the primary school and the continuation at high school

Table 1. School Performance in the primary school and the continuation at high school

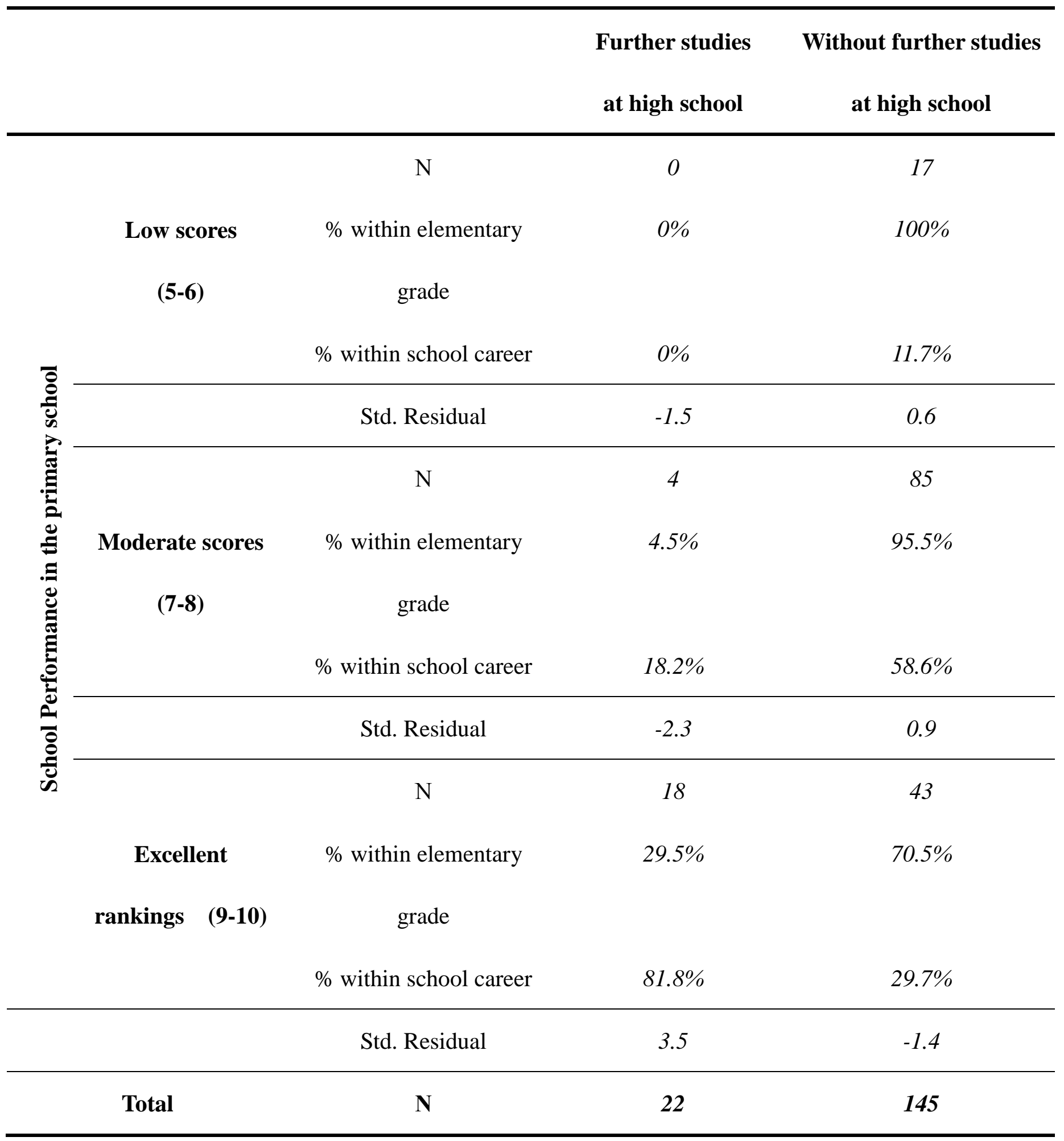




\section{Macrothink}

Journal of Sociological Research

ISSN $1948-5468$

2016, Vol. 7, No. 1

The $\mathrm{x}^{2}$ analysis gives statistically significant relationship $\left\{\mathrm{x}^{2}(2)=22.67\right.$ and $\left.\mathrm{p}=0.0005<0.05\right\}$ between school performance in primary school and further study, or not, in high school. It seems (Table 1) that Roma children with excellent scores in primary school exhibit much larger attendance rates in high school (29.5\%) compared to those with moderate $(4.5 \%)$ and low scores $(0 \%)$.

Further descriptive analysis between these variables showed that in high school were attended only those children who were rated in primary school with honors (9-10). Of these, $80 \%$ (8 children) had a poor performance in first grade and 2 children (20\%) moderate performance. Even in second grade of $75 \%$ (three children) are rated with low grades and one child $(25 \%)$ with moderate. Finally, in third grade both children $(100 \%$ of those who experienced performances in this class) also scored low grades.

For two more children with excellent performance at primary school, who continued in high school, we have no rankings because of their attendance in first grade during the survey period. Finally, four children who were gathering moderate scores in primary school, continued until high school. Two of them discontinued attendance in high school, (virtual items) and the other two were still attending the first grade in the survey period. However, there were still four children who continued in high school, but not included in the analysis, since we had no information about their score at primary school (collectively, $26(14.7 \%)$ of 177 children continued in high school).

2. Gender, school performance in primary school, direction selection in high school and admission to Universities

Of all children, only three (one boy and two girls) graduated high school, and had graduated with honors (9-10) from primary school. Their preferences in directions were for the boy technological while for girls the theoretical and positive. Only one of them (one of the girls) involved in entrance exams, but failed to introduce in a tertiary institution. 
3. School performance in primary school and dropout

Table 2. School performance in primary school and subsequent dropout in Secondary/High school

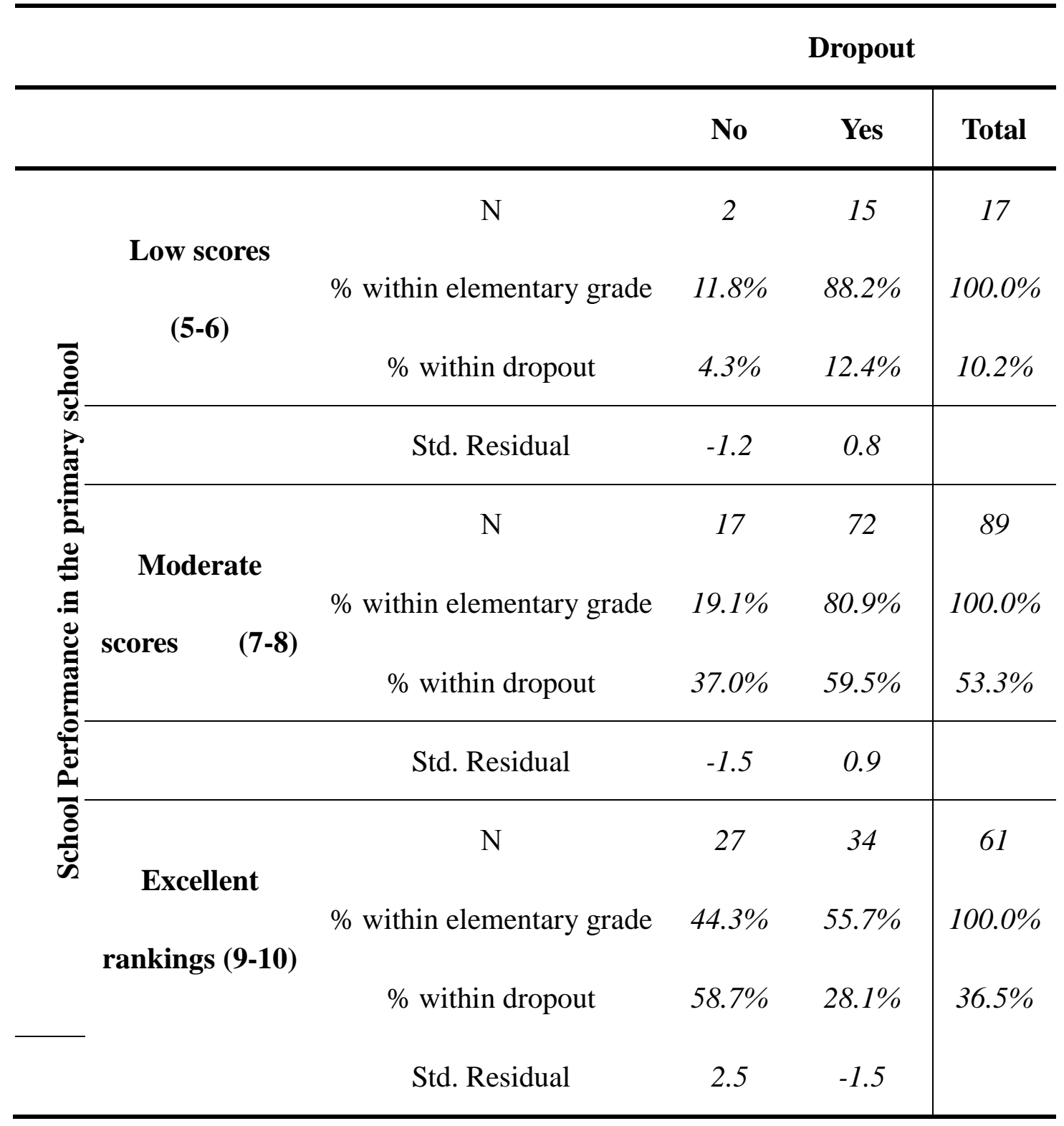

The relationship between variables "school performance in primary school" and "dropouts" in subsequent course in high school, seems to be statistically significant $\left\{x^{2}(2)=13.84\right.$ and $\mathrm{p}=0.001<0.05)$.

More specifically, from the above Table 2 and standardized residuals seems that Roma children with excellent scores in primary school have obviously smaller leakage rates $(55.7 \%$ and Std. Residual=2.5) in future course of secondary school and high school, than those with low $(88.2 \%)$ and those with moderate scores $(80.9 \%)$. So, the factor "school performance" in primary school therefore seems to be important for students' entire school career. 
4. Performance in compulsory education

Table 3. Correlation between performance in Primary and Secondary School

\begin{tabular}{|c|c|c|c|c|}
\hline & & \multicolumn{3}{|c|}{ Classes } \\
\hline & & $1^{\text {st }}$ grade & $2^{\text {nd }}$ grade & $3^{d}$ grade \\
\hline & $\mathrm{N}$ & 61 & 42 & 29 \\
\hline Primary & Correlation & .237 & .219 & .324 \\
\hline \multirow[t]{3}{*}{ school } & Coefficient & & & \\
\hline & Sig. (1-tailed) & .033 & .081 & .043 \\
\hline & $\mathrm{N}$ & 65 & 45 & 32 \\
\hline \multirow{4}{*}{$1^{\text {st }}$ grade } & Correlation & 1.000 & .581 & .491 \\
\hline & Coefficient & & & \\
\hline & Sig. (1-tailed) & .000 & .000 & .002 \\
\hline & $\mathrm{N}$ & 45 & 47 & 34 \\
\hline \multirow{4}{*}{$2^{\text {nd }}$ grade } & Correlation & .581 & 1.000 & .835 \\
\hline & Coefficient & & & \\
\hline & Sig. (1-tailed) & .000 & .000 & .000 \\
\hline & $\mathrm{N}$ & 32 & 34 & 34 \\
\hline \multirow{3}{*}{$3^{d}$ grade } & Correlation & .491 & .835 & 1.000 \\
\hline & Coefficient & & & \\
\hline & Sig. (1-tailed) & .002 & .000 & .000 \\
\hline
\end{tabular}

By the Spearman's correlation analysis (factor $r$ ) applied, statistically significant correlations 
were found only between the performance of classes of secondary school (between $1^{\text {st }}$ and $2^{\text {nd }}$ grade, $\mathrm{p}=0.0005<0.016$, between $1^{\text {st }}$ and $3^{\mathrm{d}}$ grade, $\mathrm{p}=0.002<0.025$ and between $2^{\text {nd }}$ and $3^{\mathrm{d}}$ grade, $p=0.0005<0.05$ ) and not between performance of primary and secondary school. Thus, we see that there is a positive, strong relationship between the performance in $1^{\text {st }}$ and $2^{\text {nd }}$ grade and $1^{\text {st }}$ and $3^{\mathrm{d}}$ grade $\left(0.581\right.$ and 0.491 , respectively), and between the $2^{\text {nd }}$ and $3^{\mathrm{d}}$ grade (0.835) in statistically significant level. There is no, however, the same intensity in the relationship between the performance in primary school and secondary school (there is a moderate, positive correlation between them), which, perhaps, be due to more lenient rating in primary school, due differentiated "teaching "assessment criteria at both levels of education.

5. School performance in primary school and stagnation

Table 4. School performance in primary school and stagnation in the further school career

Stagnation

No stagnation At least once

Total

at all

$\mathrm{N}$

0

17

17

Low scores

(5-6)

$\begin{array}{llll}\% \text { within elementary grade } & 0 \% & 100 \% & 100 \%\end{array}$

$\%$ within retention

$0 \%$

$12.4 \%$

$10.2 \%$

Std. Residual

$-1.7$

0.8

\begin{tabular}{ccccc}
\hline \multirow{2}{*}{$\begin{array}{c}\text { Moderate } \\
\text { scores (7-8) }\end{array}$} & \% within elementary grade & 12 & 77 & 89 \\
& \% within retention & $40 \%$ & $86.5 \%$ & $100 \%$ \\
\hline \multirow{2}{*}{ Excellent } & Std. Residual & -1.0 & $56.2 \%$ & $53.3 \%$ \\
\hline rankings (9-10) & \% within elementary grade & $29.5 \%$ & 0.5 & 61 \\
& \% within retention & $60 \%$ & $70.5 \%$ & $100 \%$ \\
\hline
\end{tabular}


Std. Residual
2.1 30
$-1.0$

\section{Total}

N

There was found a statistically significant relationship between the two variables $\left\{x^{2}(2)=10.451\right.$ and $\left.p=0.0005<0.05\right\}$ and even among Roma children with excellent scores in primary school and those with low. In other words, as seen from Table 4, there is no child with low scores in primary school, who does not remain stagnant, even once in a class in the further course of secondary school (high school is not attending any of them anyway), while those which have been rated excellent or moderate scores in primary school, $29.5 \%$ and $13.5 \%$ of children respectively, do not stay stagnant in any class during their further studies.

6. School performance in primary school and stagnation (further analysis)

Table 5. School performance in primary school and stagnation type

\section{Stagnation type}

\begin{tabular}{|lll} 
No stagnation & $\begin{array}{l}\text { Stagnation } \\
\text { because of }\end{array}$-o & Stagnation \\
at all & because of \\
& inadequate & school \\
& schooling & performance
\end{tabular}

$\mathrm{N}$

0

16

1

17

\begin{tabular}{llllll}
$\begin{array}{l}\text { Low scores } \\
(\mathbf{5 - 6 )}\end{array}$ & $\%$ within elementary grade & $0 \%$ & $94.1 \%$ & $5.9 \%$ & $100 \%$ \\
& \% within retention & $0 \%$ & $13.1 \%$ & $5.9 \%$ & $10.2 \%$ \\
\hline & Std. Residual & -1.7 & 1.0 & -0.6 & \\
\hline & $\mathrm{N}$ & 10 & 69 & 10 & 89
\end{tabular}

\begin{tabular}{llllll}
$\begin{array}{l}\text { Moderate } \\
\text { scores (7-8) }\end{array}$ & \% within elementary grade & $11.2 \%$ & $77.5 \%$ & $11.2 \%$ & $100 \%$ \\
& \% within retention & $35.7 \%$ & $56.6 \%$ & $58.8 \%$ & $53.3 \%$ \\
\hline & Std. Residual & -1.3 & 0.5 & 0.3 & \\
\hline $\begin{array}{l}\text { Excellent } \\
\text { rankings } \\
(\mathbf{9 - 1 0})\end{array}$ & $\mathrm{N}$ & 18 & 37 & 6 & 61 \\
\hline
\end{tabular}


$\%$ within retention

$64.3 \%$

$30.3 \%$

$35.3 \%$

$-0.1$

Std. Residual

2.4

$-1.1$

122

17

167

The relationship between the two variables occurs statistically significant $\left\{x^{2}(4)=13.35\right.$, with Monte Carlo Sig. $=0.01<0.05\}$. We see again that the statistical significance relates in particular to the first level of the variable "stagnation". However, it is worth noting that the vast majority of children with low scores in primary school $(94.1 \%)$ and the majority of those with moderate and excellent performance $(77.5 \%$ and $60.7 \%$, respectively) are stationary because of absences. The descriptive data presented at the end of this study, show overconcentration of stagnation rates because of absences in $1^{\text {st }}$ grade of secondary school.

7. Stagnation and further schooling

Table 6. Stagnation and further schooling in high school

Further

schooling

in high school

\begin{tabular}{llll}
\hline & & No & Yes \\
\hline & $\mathrm{N}$ & 17 & 24 \\
No retention at all & $\%$ within retention & $41.5 \%$ & $58.5 \%$ \\
& $\%$ within school career & $11.3 \%$ & $92.3 \%$ \\
& $\mathrm{~N}$ & 134 & 2 \\
\hline & $\%$ within retention & $98.5 \%$ & $1.5 \%$ \\
\hline Total & $\%$ within school career & $88.7 \%$ & $7.7 \%$ \\
\hline
\end{tabular}

The relationship between these variables are statistically significant $\left\{x^{2}(1)=77.38\right.$ and $\mathrm{p}=0.0005<0.05$, with the correction of Yates. It seems that, whether a Roma child continues in high school, is depending on whether it has experienced stagnation in a previous level of 
education. Obviously, the relationship is not causal, however, shows the great influence of the first variable in the second. Table 6 shows clearly that the vast majority of Roma children (98.5\%) that have remained stagnant at least once in the past, does not continue to high school. After all, even by those they have never been stagnant, only almost half $(58.5 \%)$ managed to continue to high school.

Table 7. Stagnation and graduation from secondary school

\section{Graduation from secondary school}

\begin{tabular}{|c|c|c|c|}
\hline & & No & Yes \\
\hline \multirow{3}{*}{ No retention at all } & $\mathrm{N}$ & 10 & 25 \\
\hline & $\%$ within retention & $28.6 \%$ & $71.4 \%$ \\
\hline & $\begin{array}{l}\% \text { within secondary school } \\
\text { graduation }\end{array}$ & $7 \%$ & $71.4 \%$ \\
\hline \multirow{3}{*}{ At least one retention } & $\mathrm{N}$ & 132 & 10 \\
\hline & $\%$ within retention & $93 \%$ & $7 \%$ \\
\hline & $\begin{array}{l}\% \text { within secondary school } \\
\text { graduation }\end{array}$ & $93 \%$ & $28.6 \%$ \\
\hline Total & $\mathbf{N}$ & 142 & 35 \\
\hline
\end{tabular}

Similar results were found in the case of secondary school attendance. The corresponding $\mathrm{x}^{2}$ analysis between the variables "stagnation" and "graduation from secondary school" showed statistically significant values $\left\{x^{2}(1)=69.38\right.$ and $p=0.0005<0.05$, with the correction of Yates $\}$. In other words, graduate from secondary school primarily those Roma children, who have never been stagnant in any of the above classes (graduated $71.4 \%$ of those who have never been stagnant, while only $7 \%$ of those who have experienced stagnation at least once before). The vast majority (93\%) of those who stayed in any class, 2 years or more, then they dropped out the secondary school. Further analysis showed that even the high school graduated only three Roma children, of which there was not anyone who had remained stagnant in any grade before. Finally, relative $\mathrm{x}^{2}$ analysis between "stagnation" and "leakage from education" showed a statistically significant relationship between these variables $\left\{x^{2}(1)=50.7\right.$ and $\mathrm{p}=0.0005<0.05$, with correction of Yates $\}$. 
Table 8. Stagnation and school dropout

\section{Dropout}

\begin{tabular}{llll}
\hline & & No & Yes \\
\hline No retention at all & \% within retention & 27 & 6 \\
& $\%$ within dropout & $81.8 \%$ & $18.2 \%$ \\
& $\mathrm{~N}$ & $51.9 \%$ & $4.8 \%$ \\
\hline \multirow{2}{*0.00}{} & $\%$ At least one retention & 25 & 119 \\
\hline Total & $\%$ within dropout & $17.4 \%$ & $82.6 \%$ \\
\hline
\end{tabular}

It seems clear from Table 8 that drop out more often those who have experienced at least once stagnation in their general studies in the educational system (thus, drops out the $82.6 \%$ of those who have stayed stagnant sometimes and only $18.2 \%$ of those who never did).

8. Gender and dropout

Table 9. Gender and school dropout

\section{Dropout}

\begin{tabular}{|c|c|c|c|c|c|}
\hline & & & No & Yes & Total \\
\hline \multirow{4}{*}{ تِّتِّ } & \multirow{3}{*}{ Boys } & $\mathrm{N}$ & 30 & 63 & 93 \\
\hline & & $\%$ within gender & $32.3 \%$ & $67.7 \%$ & $100 \%$ \\
\hline & & $\%$ within dropout & $57.7 \%$ & $50.4 \%$ & $52.5 \%$ \\
\hline & Girls & $\mathrm{N}$ & 22 & 62 & 84 \\
\hline
\end{tabular}




\begin{tabular}{lllll} 
& \% within gender & $26.2 \%$ & $73.8 \%$ & $100 \%$ \\
& \% within dropout & $42.3 \%$ & $49.6 \%$ & $47.5 \%$ \\
\hline Total & $\mathbf{N}$ & $\mathbf{5 2}$ & $\mathbf{1 2 5}$ & $\mathbf{1 7 7}$ \\
\hline
\end{tabular}

There was not found any statistically significant relationship between the two variables $\left\{x^{2}(1)=0.52\right.$ and $p=0.47>0.05$, with correction of Yates $\}$. In other words, Roma children drop out at very high levels, regardless of their gender ( $73.8 \%$ girls, $67.7 \%$ boys).

9. Gender and school performance in compulsory education and post-compulsory secondary education

Table 10. Gender and school performance in compulsory and post-compulsory secondary education

\begin{tabular}{|c|c|c|c|c|}
\hline Education level & Gender & $N$ & Mean Rank & Sum of ranks \\
\hline \multirow{3}{*}{ Primary school } & Boys & 91 & 76.80 & 6988.50 \\
\hline & Girls & 76 & 92.63 & 7039.50 \\
\hline & Total & 167 & & \\
\hline \multirow{3}{*}{ Secondary school $1^{\text {st }}$ grade } & Boys & 33 & 32.18 & 1062.00 \\
\hline & Girls & 32 & 33.84 & 1083.00 \\
\hline & Total & 65 & & \\
\hline \multirow{3}{*}{ Secondary school $2^{\text {nd }}$ grade } & Boys & 25 & 20.90 & 522.50 \\
\hline & Girls & 22 & 27.52 & 605.50 \\
\hline & Total & 47 & & \\
\hline \multirow{3}{*}{ Secondary school $3^{\text {d }}$ grade } & Boys & 17 & 15.35 & 261.00 \\
\hline & Girls & 17 & 19.65 & 334.00 \\
\hline & Total & 34 & & \\
\hline
\end{tabular}


According to Mann-Whitney analysis we have values: $U=2802.5$ with $p=0.03<0.05, \mathrm{U}_{1}=501$ with $\mathrm{p}=0.71>0.05, \mathrm{U}_{2}=197.5$ with $\mathrm{p}=0.09>0.05$ and $\mathrm{U}_{3}=108$ with $\mathrm{p}=0.19>0.05$ for primary school and three grades of secondary school, respectively. Only in the first case (performance in primary school) there is a significant difference between boys and girls. There is a tendency for girls to outweigh slightly in all grades, although this does not constitute a significant difference in statistical level. Generally, girls have significantly better performance than boys only in primary school level, while in secondary school the performance of both is compensated and limited in low levels.

Finally, in high school level, in first grade only the $1.2 \%$ of children have got moderate or excellent scores, the $0.6 \%$ in $2^{\text {nd }}$ grade and no child in $3^{\mathrm{d}}$ grade. Simple descriptive crosstabulation analysis ${ }^{1}$ showed that in the $1^{\text {st }}$ grade $80 \%$ of boys and $86 \%$ of girls gathered in low scores, while only two children -a boy and a girl- showed moderate performance. Worse, in the 2nd grade, the only boy and the $4 / 5$ of girls fell to poor performance, while only a girl got high score. Finally, in the 3rd grade, three children ( 1 boy and 2 girls) were limited low and were the only ones who manage to graduate high school.

10. Gender and secondary school graduation

Table 11. Gender and secondary school graduation

\section{Graduation}

\begin{tabular}{|c|c|c|c|c|c|}
\hline \multicolumn{3}{|c|}{ Gender } & \multirow{2}{*}{$\frac{N o}{76}$} & \multirow{2}{*}{$\frac{\text { Yes }}{17}$} & \multirow{2}{*}{$\begin{array}{l}\text { Total } \\
93\end{array}$} \\
\hline & & $N$ & & & \\
\hline & & $\%$ within gender & $81.7 \%$ & $18.3 \%$ & $100 \%$ \\
\hline & & $\begin{array}{l}\% \text { within secondary school } \\
\text { graduation }\end{array}$ & $53.5 \%$ & $48.6 \%$ & $52.5 \%$ \\
\hline & & $N$ & 66 & 18 & 84 \\
\hline & Girls & $\%$ within gender & $78.6 \%$ & $21.4 \%$ & $100 \%$ \\
\hline 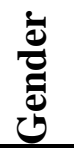 & & $\begin{array}{l}\% \text { within secondary school } \\
\text { graduation }\end{array}$ & $46.5 \%$ & $51.4 \%$ & $47.5 \%$ \\
\hline
\end{tabular}

\footnotetext{
${ }^{1}$ The extremely small sample of the Roma children who continued their studies in high school (12 children in $1^{\text {st }}$ grade, 6 in $2^{\text {nd }}$ and 3 in $3^{\text {rd }}$ grade) did not permitted us to carry out a statistical criterion of Inferential Statistics.
} 
The relationship between the variables "gender" and "graduation from secondary school" is not statistically significant $\left\{x^{2}(1)=0.11\right.$ and $p=0.74>0.05$, with Yates correction $\}$. In other words, Roma boys and girls graduating with approximately equal percentages $(18.3 \%$ and $21.4 \%$, respectively) from secondary school. However, the vast majority of Roma children fail to graduate from compulsory education regardless of their gender (only 19.8\% of them graduated). On further analysis, relating to the continuation of studies in post-compulsory secondary education showed that even fewer boys and girls enrolled in high school $(11.8 \%$ and $17.9 \%$, respectively).

11. Gender and stagnation

Table 12. Gender and stagnation

\section{Stagnation}

\begin{tabular}{|c|c|c|c|c|}
\hline Gender & & No stagnation at all & At least once & Total \\
\hline \multirow{3}{*}{ Boys } & $N$ & 21 & 72 & 93 \\
\hline & $\%$ within gender & $22.6 \%$ & $77.4 \%$ & $100 \%$ \\
\hline & $\%$ within retention & $60 \%$ & $50.7 \%$ & $52.5 \%$ \\
\hline \multirow{3}{*}{ Girls } & $N$ & 14 & 70 & 84 \\
\hline & $\%$ within gender & $16.7 \%$ & $83.3 \%$ & $100 \%$ \\
\hline & $\%$ within retention & $40 \%$ & $49.3 \%$ & $47.5 \%$ \\
\hline Total & & 35 & 142 & 177 \\
\hline
\end{tabular}

By $\mathrm{x}^{2}$ analysis, there are no statistically significant relationship emerged between the variables "gender" and "stagnation» $\left\{\mathrm{x}^{2}(1)=0.64\right.$ and $\mathrm{p}=0.43>0.05$, with Yates correction $\}$. That means that the vast majority of Roma children remain stagnant in any or some classes during their attendance at our country's educational system, regardless of their gender. However, individual emerging trends in favor of boys, which seem to have slightly smaller repetition rates than girls $(77.4 \%$ and $83.3 \%$, respectively) do not constitute, however, important relationship on a statistical level.

Summarizing, the research population consists of 177 Roma children, of which 93 (52.5\%) 
were boys and 84 girls. 121 (68.4\%) discontinued studies during their secondary school years, $13(7.3 \%)$ were continuing their studies in secondary school during the period of the survey, 9 moved to another secondary school and $34(19,2 \%)$ were able to graduate. Of these 34 , only 26 continued in high school (14.7\% of total 177), of which 5 dropped out during their attendance at this, another 12 have continued their studies at this during the survey period, one moved to another high school and 5 in Technical Vocational High Schools, and only three $(1.7 \%$ of the total of 177$)$ graduated.

Also, multiple response analysis showed that $78.7 \%$ (299 of the 380) of stagnations that occurred in total, took place in the $1^{\text {st }}$ grade of secondary school due to poor attendance and repetition frequency of 1-5 times. Moreover, 70.6\% (125 children) of population dropped out from secondary or high school. More specifically, 101 of them (57.1\%) dropped out 1st grade of secondary school, $13(7.3 \%)$ in $2^{\text {nd }}$ grade, $6(3.4 \%)$ in $3^{\mathrm{d}}$ grade and $5(2.8 \%)$ in $1^{\text {st }}$ grade of high school.

\section{Discussion}

High scores in primary school have positive effect on children's subsequent school career (Author, 2010). The same happens in the case of Roma, who are traditionally unable to meet the increased demands of the education system and are permanently excluded (Ginsburg, 1986; McLeod \& Nonnemaker, 2000; Biro et al., 2006). So, we cannot overlook the fact that in secondary and high school proceed only Roma children who excel in primary school, but neither can be ignored that Roma children who excel in primary school are unable to experience such excellent performance in secondary and high school. Instead, they drop out early from the educational system. This is due to the fact that the performance in primary school relate to the final overall grade of any class, which is notoriously resulting from the average of several disciplines and customary generously rated by teachers. It would be quite enlightening, if we had the performance of Roma children in language, in which area is likely to be much lower. As mentioned in the first part of the article, the basic lack of educational system on the issue of teaching children with mother tongues other than the official Greek is an important factor in shaping negative learning conditions. Researchers on Roma issues support that "literacy which does not include literacy in one's mother tongue, may result in an orphaned intellect" (Acton \& Davies, 1979: 92). Useful feedback could also be derived from relevant research concerning immigrant children. Cummins (1996) supports the teaching of immigrant children in their mother tongue alongside the language of the host country in order to develop the requisite academic proficiency in all subjects without exception, even those traditionally considered that need less language, such as Mathematics and Science. Reinforcing this point, is the very illuminating fact that former Soviet Union managed to overcome the known rationalizations and ideologies on orality of language of Gypsies and the lack of writing by doing the obvious; building an alphabet for Roma in Roman characters and alphabetizing Roma children in their mother tongue, giving due consideration to such an important issue (Tsiakalos, 2006).

Scores between different grades of Secondary school seem to be strongly correlated, which refers to known adhesion tension of teachers in scores of past years (Tsianakas, 2011), based 
on prejudices, which advocate the self-fulfilling prophecy (Rosenthal \& Jackobson, 1968).

The inability of the school to hold in the Roma children is the inability of school to respond to the particular needs and interests of Roma children, racist stereotypes and negative prejudices diffused in the educational process on the specific population group, but also the complete devaluation of their culture and mother tongue from formal educational system, extreme poverty and illiteracy that affect their families, frequent trips for financial reasons. All these are some of the important factors that jointly shape the final educational exclusion suffered by these children and disprove popular, unfortunately, falsehoods, which consider school failure of Roma as an act of resistance or hostility on their part towards school (Tsiakalos, 2006). It has been clear by the fact that the school dropout in secondary education is presented by overwhelming proportions and regardless of factors such as gender, which seem to play a role on the issue of school dropouts and children performance of other population groups. The same is observed with the stagnation rates. However, there has been a tendency (although statistically insignificant) according to which the girls repeat the same class more often than boys, while the latter prefer dropping out from school. Moreover, girls outweigh significantly to performance in primary school than boys while in secondary school differences are compensated, since the vast majority of children exhibit poor performance, regardless of their gender (Joyce et al., 2009).

The vast majority of children stagnation, once or more times upon entering the secondary school, leads us to believe that it is probably fictitious entries in most cases, without any attendance in secondary compulsory education (Author, 2010) and supports the view that the drop out is also affected by the transition from one level of education to another (Zigos, 1987) .

We could say that our results constitute an extended school failure of Roma children, especially during their study in secondary school. Therefore, it is confirmed an earlier related research, on which two schools surveyed and where only one student was able to graduate secondary school and enroll high school. The location of schools, strict, organizational structure and one-cultural, ethnocentric mode of operation, together with the consequent role of teachers, and a series of social and economic factors (such as poverty, child labor, basic shortcomings in living and housing conditions) lead those children in non-completion of compulsory nine-year education, challenging the fake argument about the equality in schools (Chatzinikolaou, 2007).

The results of this survey support what has been recorded in previous surveys in Greece in connection with school access and educational path of Roma children. Thus, despite of the nationwide educational programs that have been implemented from 1996 to now, there remains a large percentage of children not attending school or presenting poor attendance and dropping out from the school system. Only a few of them continue in secondary and high school, while the overwhelming percentage of children does not attend higher education.

According to the results of this study, a key factor in the overall school career of children is the performance in elementary school, as it significantly affects the dropping out rates in the subsequent secondary and high school attendance. Poor performance in primary school 
foresee stagnation in some grade in secondary school or not any further attendance in high school in the future, while the moderate and excellent rates are associated with normal school career and further study at secondary school. The vast majority of Roma children remain stagnant in one or more grades during their attendance in the educational system. The children who experience the stagnation in any grade they drop out of school in the future and there is no chance to reach high school attendance. The most important factor for stagnation seems to be their absences and not their performance.

Based on the results, we consider that even today are updated the three points that were included in the 1987 synthesis report of the first research carried out at European level on the educational situation of Roma children in Europe: «a)Too little attention has been paid to the values and dynamics of education within the traveler family, and as a result, pedagogical theory and practice are usually opposed to family education, instead of being based upon it, b)The way in which Gypsy and Traveler parents educate their children should not be judged in the light of how the society surrounding them educates theirs, c) The development of schooling both in intensity and in duration, in European society; the way in which it has taken on more and more of the family's educational role, and correspondingly the degree to which families have relegated this responsibility to the school system, have gradually transformed "schooling" into a synonym for "education". We speak of the "educational system" when we mean the school system; we delegate total responsibility to the "Minister for Education" or 'Department of Education'. If this is the case for many, it is not so for all, and we must emphasize that there are those-including the Gypsies-for whom schooling is only a part (and sometimes not even that) of the education of their children» (Liegeois, 1987:45-46).

\section{Conclusions}

It is customary, therefore, the school failure of Roma children be given summarily and defiantly lightly to their specific characteristics. In such cases they mobilized ideologies (Roma are hostile to the school, responsible parents and their overall lifestyle, etc.) in order to blame the victims themselves. This is a practice of broader policy assimilation or exclusion, taking place against anyone differs from the dominant norm. Obviously, deep poverty which exists in the majority of the members of Roma communities in our country is not considered. Poverty and a wider social exclusion, which convert childhood biological phase in social good attached or cut down by people at will, not on the basis of their alleged culture, but on the basis of a very specific socio-economic and political system. Reducing the effects of certain antisocial policies in causes of the problem of school failure of those children, a pronounced political and social scandal is placed, despite the tragedy and the breadth of shows not to cause turbulence. Therefore, with the emergence of the absolute size of the educational exclusion of Romani children in our country, we aim for something special; to annoy and push, making visible the concealed inequality in its true dimensions, to finally reverse the conditions of reproduction of social conditions exclusion of the majority of society, starting with the Roma.

(Finally, we could say that in order to investigate the educational characteristics of the Roma 
population in Greece, we have to take into account the "deep" poverty of the Roma population. This poverty and the broader social exclusion of this very population in fact convert the biological age of the Roma children to a social good that is attributable to or cut down by people at will, based on their particular supposed culture, but on the basis of a very specific socio-economic and political system imposed on them. The Greek society and the educational system convert the effects of certain antisocial policies to causes of the school failure of these children creating an unmistakable political and social scandal which remains invisible).

It is important for each national team to know that does not constitute a fixed entity, defined ontologically, but a historical construction, a product of timeless complex process in which the partakers reconstruct through historical action and cultural heritage biographical continuities between ancestors and selves as an identified group (Weinreich 1989).

\section{References}

Acton, Th., \& Davies , G. (1979). Educational Policy and Language Use Among English Romanies and Irish Travellers (Tinkers) in England and Wales". In: Ian. G. Hancock (Ed.), Romani Sociolinguistis. International Journal of the Sociology of Language, n19, Mouton, The Hague, Paris, New-York.

Biro, M., Novović, Z., \& Tovilović, S. (2006). Kognitivno funkcionisanje edukativno zapuštene dece predškolskog uzrasta, Psihologija, 39, 183-204.

Biro M., Smederevac S., \& Tovilović S. (2009). Socioeconomic and cultural factors of low scholastic achievement of Roma children. Psihologija 42, 3, 273-288.

Brüggemann, C. (2012). Roma education in comparative perpective.Analysis of the UNDP/World Bank/EC regional Roma Survey. Roma inclusion Working Papers. Bratislava:UNDP Regional Bureau for Europe and the CIS.

Cummins, J. (1996). Negotiating Identities: Education for empowerment in a diverse society. Ontario-California: Association for Bilingual Education.

Englud, M. M., Luckner, A. E., Whaley, G. L., \& Egeland, B. (2004). Children's achievement in early elementary school: Longitudinal effects of parental involvement, expectations, and quality assistance. Journal of Educational Psychology, 96, 723-730.

Evrodiastasi-Oikokoinonia, (2008). Meleti gia tin Katagrafi tis Ifistamenis Katastasis ton Roma stin Ellada. Apologismos Draseon ke Ekponisi Shediou Drasis gia tin 4th Programmatiki Periodo. (A study for the documentation of the existing situation of Roma in Greece. Evaluation of activities and development of an Action Plan for the $4^{\text {th }}$ Programming Period). Athens.

Forray, K. (2000) The situation of the Roma/Gypsy community in Central and Eastern Europe. Pécs: University of Pécs, Department of Romology. 


\section{MInstitute ${ }_{\text {Mnk }}^{\text {Macrothin }}$}

Forray, K., (2003). Results and Problems in the Education of Gypsy Community. European Education, 34(4), 70 - 90.

FRA, European Union Agency for Fundamental Rights - UNDP, Europe and the CIS. (2012). The situation of Roma in 11 EU Member States. Survey results at a glance. Luxemburg: Publications Office of the European Union.

Ginsburg, H. P. (1986). The myth of the deprived children: new thoughts on poor children. In: U. Neisser (Ed.). The School Achievement of Minority Children: New Perspectives. New York: Lawrence Erlbaum Associates, 169-189.

Goffman, E. (1963). Stigma: Notes on the Management of Spoiled Identity. Englewood Cliffs, NJ: Prentice-Hall.

Havas, G. (2002). The School as Breakout Point. In: Kállai, E. (ed.) The Gypsies/The Roma in Hungarian Society. Budapest: Regio, 107-125.

Joyce, Br., Weil, M, \& Calhoun, Em. (2009). Didaktiki Methodologia. Didaktika Montela [Methodology of Teaching. Models of Teaching]. K. Kasimati (ed.) ( $1^{\text {st }}$ edition). Athens: ELLIN.

Liegeois, J. P. (1987). School Provision for Gypsy and Traveller Children: A Synthesis Report. Brussels-Luxembourg: Office for Official Publications of the European Communities.

Liegeois, J.P. (1994). Roma, Gypsies, Travellers. Strasbourg: Council of Europe.

Loyal, S.\& Quilley, S. (2004). An Introduction to Norbert Elias. In: S. Loyal \& S. Quilley, S. (eds). The Sociology of Norbert Elias. Cambridge: Cambridge University Press.

McLeod, J., \& Nonnemaker, J. (2000). Poverty and child emotional and behavioral problems: Racial/ethnic differences in processes and effects. Journal of Health and Social Behavior, 41, 137-161.

Mentor, R. (1948). The Self-Fulfilling Prophecy. The Antioch Review. 8 (2), 193-210. Summer 1948. Recovered from: http://www.jstor.org/stable/4609267.

Okely, J. (1983). The Traveller Gypsies. G. Britain: Syndicate of the University of Cambridge.

Papakonstantinou, G., Vassiliadou, M., \& Pavlis-Korres, M. (1st fasi: 1998, 2nd fasi: 1999). Ikonomiko-Kinoniko-Politismiki Katastasi ton Roma stin Ellada [(First Phase: 1998, Second Phase: 1999). Economic-Social-Cultural Situation of Roma in Greece]. Greece: University of Ioannina.

Pavlis-Korres, M. \& Sideris, A. (1990). I Tsiggani tis Agias Varvaras ke tis Kato Ahaias. (Tsigganes of Agia Varvara and Kato Ahaia). Athens: GGLE (in Greek).

Pavlis-Korres, M. \& Leftheriotou, P. (2011). Approaching the different. Notes addressed to teachers participated in the program "Education of Roma children" University of Athens-IDEKE. Athens. 
Pavlis-Korres, M. (2014). Roma and the greek educational system. In conference Proceedings, entitled: Children Age: Sociological, Cultural, Historica and Pedagogical Dimension. Laboratory of Social Sciences, Research Center "Childhoods Societies"-Wuppertal University, Hellenic Educational Society, Hellenic Sociological Society, European Sociological Association, Childhood Stream, 129-135.

Posavec K., \& Hrvatic N., (2000). Intercultural education and Roma in Croatia, Intercultural Education, 11, 1, 93-105.

Rosenthal, R., \& Jackobson, L. (1968). Pygmalion in the Classroom. Expectations and Pupils. University of Oak-USA: Intellectual Development, Holt, Rinehart \& Winston.

Schiefele, H. (1986). Kinitra mathisis os skopos ke proipothesi gia mia apotelesmatiki didaskalia. \{Motivation as a learning objective and a prerequisite for effective teaching. (trans: Lykidi, S.)\}. In: Educational Inspection 5, 199-233: Thessaloniki: Afoi Kyriakidi (in Greek).

Spanouli, A. (2014). Tsiganes-support in daily life. Notes for the educator. Educational material for the Municipal Centers of Lifelong Learning. Athens: Hellenic Open University.

Synergon, O., (2008) Eksoteriki Aksiologisi tu programmatos "Entaksi tsigganopedon sto sholio" (External Evaluation Report for the program "Integration of Roma Children in School”), July 2008, 79 (in Greek).

Tourtouras, Chr. (2010). Sholiki apotihia ke apoklismos. I periptosi ton pedion apo tin proin Sovietiki Enosi [School failure and exclusion. The case of children from the ex Soviet Union]. Athens: Epikentro.

Tsiakalos, G. (2006). Apenanti sta ergastiria tou ratsismou [Towards the laboratories of racism]. Athens: Tipothito-Gutenberg.

Tsianakas, Ev. (2001). I axiologisi ton mathiton tis protovathmias ekpedefsis stin Agglia ke stin Ellada. Sigritiki theorisi [The assessment of the students of primary education in England and in Greece. A comparative consideration]. Athens: Kiriakidis brothers.

Hatzinikolaou, A. (2007). Sholio iso gia pedia anisa. Mia ideologiki proklisi stin ekpedefsi gia pedia kinonika apoklismenon omadon. Ena paradigma apo tin ekpedefsi ton pedion Roma [Equal school for unequal children. An ideological challenge in education about children of socially excluded groups. A paradigm from the education of Roma children]. Sta: Praktika tou 4ou Panelliniou Sinedriou, me thema: Sholio iso gia pedia anisa. Elliniko Instituto Efarmosmenis Pedagogikis ke Ekpedefsis [In: Proceedings of the 4th Hellenic Conference, entitled: Equal School for Unequal Children. Greek Institute of Applied Pedagogics and Education]. Athens: 4-6 May.

Weinreich, P. (1973). A Case Study Approach to the Analysis of Identity Structure. University of Bristol. SSRC. Research Unit on Ethnic Relations.

Zigos, S. (1987). I enniahroni ipohreotiki ekpedefsi (Mithos ke pragmatikotita) [The nine-years compulsory education (Myth and reality)]. Nea Pedia, 44, 69-81. 